\title{
Does the Bulgarian Health Care System Need a Health Ombudsman?
}

\author{
Nigyar Dzhafer ${ }^{1}$, Tzekomir Vodenicharov ${ }^{1}$, Janis Papathanasiou ${ }^{2}$ \\ ${ }^{1}$ Department of Health Policy and Management, Faculty of Public Health, Medical University of Sofia, Bulgaria \\ ${ }^{2}$ Department of Imaging, Allergology and Physiotherapy, Faculty of Dental Medicine, Medical University of Plovdiv, Bulgaria; Department of Kinesitherapy, \\ Faculty of Public Health, Medical University of Sofia, Bulgaria
}

Corresponding author: Janis Papathanasiou, Department of Imaging, Allergology and Physiotherapy, Faculty of Dental Medicine, Medical University of Plovdiv, 3 Hristo Botev Blvd., 4002 Plovdiv Bulgaria. E-mail: giannipap@yahoo.co.uk; Tel: +359889101178

Received: 27 Oct 2019 Accepted: 20 Nov 2019 Published: 30 June 2020

Citation: Dzhafer N, Vodenicharov T, Papathanasiou J. Does the Bulgarian health care system need a health ombudsman? Folia Med (Plovdiv) 2020;62(2):391-7. doi: 10.3897/folmed.62.e47655.

\begin{abstract}
Background: The Office of the Ombudsman of the Republic of Bulgaria (ORB) is an independent constitutional body elected by Bulgarian Parliament in 2005. It serves to protect the rights of all citizens, including the rights of patients, children, people with disabilities, minorities, foreigners, etc. Bulgarian healthcare users complain when they feel that the healthcare system (HCS) has failed their needs or they have been recipients of an inappropriate treatment.
\end{abstract}

Aim: The aim of the present study was to analyze the structure and dynamics of all complaints from Bulgarian healthcare users referred to the ORB over a 13-year period (2005 - 2018).

Materials and methods: Retrospective documental research was used in the present study. The data included the complaints obtained from the official annual reports of the ORB that are available online. Bibliographic and documental searches were also used as sources. The complaints were analyzed by their annual distribution and classified by problem areas in the HCS.

Results: Between 2005 and 2018, there were a total of 3288 complaints filed to ORB against HCS. In 2015, 368 complaints were received by ORB from Bulgarian healthcare users and from various patient organizations concerning problems in the HCS. The filed complaints to ORB increased by $82 \%$ in $2016(n=421)$. In 2017 , the overall number of ORB-referred complaints amounted to 494 , and in 2018 their number was as high as 607, which represents an increase by 23\% compared to the number of complaints in 2017.

Conclusion: The great number of complaints referred to ORB about the HCS over the last four years strongly suggests that the institution of the Ombudsman in Bulgaria enjoys high confidence among Bulgarian healthcare users.

\section{Keywords}

Ombudsman, Bulgarian health users, complaints, limitations, patients' rights, access

\section{BACKGROUND}

Despite the ambitious intentions of healthcare policy makers in Bulgaria during the last two decades to reform the national health care system (HCS) transforming it from the centralized Semashko healthcare model into the Bismarck model, there was no significant improvement in the design, functions and regulation of this institution. ${ }^{1}$ It is still characterized by a stronger degree of centralization than many other European countries, restricted access, poor quality, and lack of patient's protection. ${ }^{2}$ Many institutions such as the Council of Ministers $(\mathrm{CoM})^{3}$, the Ministry of Health $(\mathrm{MH})^{4}$, the Executive Agency Medical Audit (EAMA) ${ }^{5}$, the National Health Insurance Fund (NHIF) ${ }^{6}$, the Bulgarian 
Drug Agency (BDA) ${ }^{7}$ as well as the National Social Security Institute $(\mathrm{NSSI})^{8}$ were involved in the drive to implement the reform in HCS. ${ }^{2}$ The above mentioned institutions have various responsibilities, and activities in HCS, but one of the most important is the protection of the patients' rights. ${ }^{9}$ Patients' rights vary in different countries and in different jurisdictions, often depending upon different ethical, judicial, insurance and economic factors. ${ }^{10}$ In April 2005, Bulgaria elected the first parliamentary ombudsman whose powers allowed this official to deal with complaints against public authorities, human rights violations as well as with those related to healthcare (HC).

The Ombudsman of the Republic of Bulgaria (ORB) is an independent constitutional body elected to protect the rights of all citizens, including the rights of patients, children, persons with disabilities, minorities, foreigners etc. $^{11,12}$ The ORB is also a part of the mechanism for the free exercise of human rights, transparency, democratic spaces for popular participation. Any citizen can turn to the Ombudsman with a complaint or a signal, including on $\mathrm{HC}$ issues. The Bulgarian healthcare users complain when they feel that the HCS has failed their needs or they have been recipients of an inappropriate treatment. The com- plaining process is a valuable democratic tool even in the field of HCS, particularly when health care users want to change decisions issued from various HC institutions, or when they want to deal with aspects of an ineffective policy.

\section{AIM}

The aim of the present study was to analyze the structure and dynamics of complaints from Bulgarian healthcare users referred to the ORB over a 13-year period (2005 2018).

\section{MATERIALS AND METHODS}

The present study was based on retrospective, documental research. The unit of analysis was the administrative office of ORB, as well the data included in the annual ORB reports analyzed by the Department of Health Policy, in the Faculty of Public Health at the Medical University of Sofia, between January and August 2019. We collected the data for a 13-year period, from 2005 to 2018, from the official

Table 1. Complaints referred to ORB by problem areas

\begin{tabular}{|c|c|c|c|}
\hline Access & Quality & Regulation & Patients' rights \\
\hline Access to HC services & Quality of HC services & Control of HC services & Effective legal protection \\
\hline $\begin{array}{l}\text { Access to the Specialized Out- } \\
\text { patient Medical Care (SOMC) }\end{array}$ & $\begin{array}{l}\text { Delayed and inadequate } \\
\text { emergency HC }\end{array}$ & $\begin{array}{l}\text { Ineffective procedures and admin- } \\
\text { istrative control }\end{array}$ & Personalized treatment \\
\hline Access to treatment abroad & $\begin{array}{l}\text { Guidelines for good medical } \\
\text { practice }\end{array}$ & $\begin{array}{l}\text { Health insurance regulation for } \\
\text { Bulgarian citizens living abroad }\end{array}$ & $\begin{array}{l}\text { Participation of citizens in } \\
\text { decision making }\end{array}$ \\
\hline Access to innovative treatment & $\begin{array}{l}\text { Establishment of medical } \\
\text { standards }\end{array}$ & Medical expertise of labour & Transplant Patients \\
\hline $\begin{array}{l}\text { Access to life-saving and life } \\
\text { support treatment }\end{array}$ & Suspected medical errors & $\begin{array}{l}\text { Implementation of European } \\
\text { health cards }\end{array}$ & $\begin{array}{l}\text { Patients with Alzheimer } \\
\text { disease }\end{array}$ \\
\hline Access to HCS by children & $\begin{array}{l}\text { Primary Outpatient Medical } \\
\text { Care }\end{array}$ & Imposing hospital limits & \\
\hline Access to health information & Quality of dental services & Medical team selection & \\
\hline $\begin{array}{l}\text { Access to rehabilitation treat- } \\
\text { ment }\end{array}$ & $\begin{array}{l}\text { Hygiene conditions and } \\
\text { hospital food }\end{array}$ & Rights of the health professional & \\
\hline \multirow{6}{*}{$\begin{array}{l}\text { HC for children with onco- } \\
\text { logical or rare diseases }\end{array}$} & & Health prevention & \\
\hline & & Regulation of Residency doctors & \\
\hline & & $\begin{array}{l}\text { National Expert Medical Board, } \\
\text { Regional Expert Medical Board }\end{array}$ & \\
\hline & & Surcharges & \\
\hline & & $\begin{array}{l}\text { Dissatisfaction with the ongoing } \\
\text { amendments of the regulations }\end{array}$ & \\
\hline & & $\begin{array}{l}\text { Prolonged deadlines for issuing a } \\
\text { decision for treatment abroad }\end{array}$ & \\
\hline
\end{tabular}


annual ORB reports, available online in the institutional website. $^{13}$

After comprehensive evaluation of the data included in these annual reports, the first and the third author (N.D. and J.P.) performed an independent analysis to classify the complaints by problem areas in BHCS. In the initial analysis of the data included in the annual reports, the authors were guided by the usual indicators used for evaluation of public health systems: accessibility, quality, regulations, and control. The second author (T.V.) compared the analyses conducted by both authors and consensual approval of the final distribution of the data was reached (Table 1). In our study we searched web resources to identify surveys regarding the ORB institution in Bulgaria that could provide additional information about its performance. The ORB submits an annual report about its activities to the National Assembly, as well as an annual bulletin. Both public reports should be submitted till March 31 of the following year and should contain information about the received appeals and signals for which the checks have completed. By law, these reports contain: cases when an interference has had a result; cases when its interference has remained without a result and the reasons for this; proposals and recommendations made, as well as, whether they have been taken in mind; the respecting of the rights and the basic liberties and the effectiveness of the acting legislation in this field; proposals and recommendations for implementing changes in the legislation; account of the expenses; other information which the ORB considers necessary for full and precise presentation of its activity. ${ }^{12,14}$ The annual reports of ORB officially available did not always contain data of results and effectiveness of interventions preventing us from including these in our analysis.

\section{RESULTS}

Since 2005, the institution of the ORB officially has been publishing reports annually about its activity.

Table 1 shows systematically the complaints included in our study, which were distributed, by problem areas, into four categories: accessibility to HCS; quality of HCS, regulation; and patient's rights.

The overall number of complaints, referred to the ORB, during a thirteen year period $(2005-2018)$ is 80219 . The complaints regarding the problems in the BHCS from the same period are $3288 .{ }^{13}$ Based on the available data, there has been a steady annual increase in the number of the complaints since the introduction of the institution of ORB in Bulgaria. In 2005, Bulgarian citizens submitted 2516 complaints, and in 2018 their number reached 12890 , which is more than 5 times increase. $1^{5,16}$ In 2005, Bulgarian healthcare users submitted 58 complaints, or $2 \%$ of the overall number of the complaints referred to the ORB. In 2018, the complaints against HCS reached 607 or $4.7 \%$ of the overall number of complaints. Table 2 presents the annual distribution of the submitted complaints to ORB over the study period (2005-2018). As shown in the table, a significant increase of the BHCS-related complaints submitted to the ORB has been observed during the last four years. In 2015, we identified 368 complaints regarding problems in the HCS submitted from the Bulgarian healthcare users, healthcare professionals, and from various patient organizations. ${ }^{17}$ After an expert evaluation, the majority of them $(n=272)$ were found to be related to restricted access to HCS, poor quality of HCS, as well, and problems in the emergency HC. In these complaints, Bulgarian health users voiced their disapproval about various decisions issued such as imposing hospital limits, and implementation of European health cards. Ninety-six of the complaints during this year addressed problems in health promotion, as well as the restricted patients' rights, and problems of the health care professionals.

We found an additional increase of the submitted complaints in 2016. ${ }^{18}$ Four hundred twenty-one complaints and alerts $(n=421)$ were submitted by Bulgarian healthcare users. They complained of restricted access to HC, surcharge, out-of-pocket payments, ${ }^{19}$ limitations in health prevention, as well as problems related to various public health institutions (e.g. the Regional Expert Medical Board). Complaints were also submitted from socially disadvantaged persons, self-employed, unemployed persons, and no income families. They complained about their health insurance rights, poor quality of $\mathrm{HC}$, including dental care, low hygiene conditions, and poor food quality in hospitals. Thus, the complaints increase within just one year by $82 \%$.

In 2017, the overall number of complaints referred to ORB amounted to 494, which represents an increase by $84 \%$ compared to 2015 , and by $17 \%$ compared to $2016 .^{20}$ The majority of the complaints $(n=170)$ by 2017 were about the limited access to HCS. In 2017, Bulgarian health users complained not only about problems related to regulation, i.e. implementation of medical expertise, but also limitations of their health insurance rights, as well as poor quality of HCS. ${ }^{21,22}$ Sixty one complaints $(n=61)$ were related to health prevention, as well as surveillance of hygiene standards and requirements in hospitals, economic compensation for treatment, as well as non- updated regulation for residency doctors. Persons with disabilities complained of their limited access to rehabilitation, treatment and services (Table 2 ).

The overall number of complaints referred to the ORB by 2018 was 607 , an increase by $23 \%$ compared to the number of complaints submitted by 2017, respectively 494 complaints, and by 44\% compared to these submitted in 2016 (421 complaints).16 Bulgarian healthcare professionals expressed their dissatisfaction regarding their low salaries. Issues voiced by disability patients described their restrictions to HCS, and rehabilitation services. Additionally in 2018, the ORB received complaints from parents whose children are on the waiting list for liver transplantation. In particular, parents claimed that in Bulgaria there is a lack of qualified pediatric transplant surgeons. 
Table 2. Annual distribution of submitted complaints to ORB over a thirteen-year period (2005 - 2018)

\begin{tabular}{|c|c|c|c|}
\hline Year & Problem Areas & $\begin{array}{l}\text { Annual } \\
\text { number of } \\
\text { complaints } \\
\text { referred to } \\
\text { ORB }\end{array}$ & $\begin{array}{l}\text { Annual } \\
\text { number of } \\
\text { complaints } \\
\text { related to HCS } \\
\quad \mathbf{n}(\%)\end{array}$ \\
\hline 2006 & $\begin{array}{l}\text { Problems regarding the Regional Expert Medical Board; Health insurance regulation for } \\
\text { Bulgarian citizens living abroad; Quality of the HC services; Access to HC services. }\end{array}$ & 2516 & $58(2 \%)$ \\
\hline 2007 & $\begin{array}{l}\text { Patient's rights; Access to the Specialized Outpatient Medical Care (SOMC); Access to } \\
\text { life-saving and life-support treatment; Quality of the HC services; Labour Expert Medi- } \\
\text { cal Commission; Ruling on claims - (Regional Health Inspectorate, Bulgarian Medical } \\
\text { Association, Bulgarian Dental Association, Regional Health Insurance Fund), Participa- } \\
\text { tion of citizens in decision making, Effective legal protection. }\end{array}$ & 3367 & $137(4 \%)$ \\
\hline 2008 & $\begin{array}{l}\text { Access to HC services (referrals, payment requirements, medical team selection); Qual- } \\
\text { ity of HC services (guidelines for good medical practice and establishment of medical } \\
\text { standards); Medical expertise of labour. }\end{array}$ & 2405 & $103(5 \%)$ \\
\hline 2009 & $\begin{array}{l}\text { Access to HC services; Quality of HC services; Ineffective procedures and administrative } \\
\text { control in the HC system; Treatment abroad; Rights of the health professionals. }\end{array}$ & 2686 & $107(4 \%)$ \\
\hline 2010 & $\begin{array}{l}\text { Delayed and inadequate emergency HC; Doubts about medical errors; HC for children } \\
\text { with oncological or rare diseases; Treatment abroad (deadlines for issuing a decision); } \\
\text { Regulations of residency doctors; Report on fitness for work; Access to HC services and } \\
\text { Quality of HC services. }\end{array}$ & 3687 & $203(5 \%)$ \\
\hline 2011 & $\begin{array}{l}\text { Patients who had undergone transplantations; Patients with Alzheimer disease; Medical } \\
\text { report ordered by a court; Access to HC services; Quality of HC services; Patient's rights. }\end{array}$ & 5530 & $196(3.5 \%)$ \\
\hline 2012 & $\begin{array}{l}\text { Patient's rights; Report on fitness for work; quality of HC; Emergency HC; Specialized } \\
\text { Outpatient Medical Care; National Expert Medical Board; Rudeness. }\end{array}$ & 5331 & $179(3.4 \%)$ \\
\hline 2013 & $\begin{array}{l}\text { Regional Expert Medical Board; National Expert Medical Board; Emergency HC and } \\
\text { quality of HC services; Primary Outpatient Medical Care; Specialized Outpatient Medi- } \\
\text { cal Care; Personalized treatment and access to innovative treatment; Rights of the health } \\
\text { care professionals. }\end{array}$ & 7320 & 247 (3.4\%) \\
\hline 2014 & $\begin{array}{l}\text { Access to HC services; Report on fitness for work; Quality of HC services; Access to } \\
\text { health information; Doubts of medical errors; Personalized treatment and access to in- } \\
\text { novative treatment regarding Bechterew's disease; Huntington's disease; Hydrocephalus } \\
\text { and Spina bifida. }\end{array}$ & 5010 & $168(3.4 \%)$ \\
\hline 2015 & $\begin{array}{l}\text { Imposing hospital limits; Dividing the work into basic and extra; Implementation of Eu- } \\
\text { ropean health cards; Access and quality of HC services; Emergency HC; Health promo- } \\
\text { tion and health prevention; HC rights and problems of the HC professionals. }\end{array}$ & 6202 & $368(3.5 \%)$ \\
\hline 2016 & $\begin{array}{l}\text { Limited access to HCS; Access to rehabilitation services for people with disabilities; } \\
\text { Health prevention; Problems with the Regional Expert Medical Board; Surcharge; Out- } \\
\text { of-Pocket Patient Payments; Socially disadvantaged persons, self-employed, unemployed } \\
\text { persons, and no income families rights for health insurance; Quality of HC services, in- } \\
\text { cluding dental services; Hygiene and living conditions in the hospitals, food. }\end{array}$ & 10640 & $421(3.96 \%)$ \\
\hline 2017 & $\begin{array}{l}\text { Access to rehabilitation services for people with disabilities; Limited access to HCS; Im- } \\
\text { plementation of medical expertise; Limitations of health insurance; Poor quality of HCS; } \\
\text { Health prevention limitations; Surveillance of hygiene standards in hospitals; Economic } \\
\text { compensation for treatment; Regulation for residency doctors. }\end{array}$ & 12635 & $494(4 \%)$ \\
\hline 2018 & $\begin{array}{l}\text { Quality of HCS; Dissatisfaction of the health care professionals from Municipal and } \\
\text { State/University Hospitals; Access to HCS; Access to HCS for children; Access to reha- } \\
\text { bilitation services for people with disabilities; Children in waiting list for liver transplan- } \\
\text { tation; Medical Expertise of health care users; Access to drugs or medical devices; Health } \\
\text { insurance limitations. }\end{array}$ & 12890 & 607 (4.7\%) \\
\hline Total & & 80219 & $3288(4.10 \%)$ \\
\hline
\end{tabular}




\section{DISCUSSION}

To our knowledge this is the first retrospective documental study carried out in Bulgaria and aimed at analyzing the structure and dynamics of the complaints from Bulgarian healthcare users referred to the ORB over a 13-year period (2005 - 2018). After a comprehensive analysis of the data included in the annual reports of the ORB, we identified some serious problems that persisted in the regulation of the BHCS during the study period. Bulgarian healthcare users highlighted the poor quality and functioning of the HCS, as well as limitations of their rights, and limitations of the health professionals rights. Difficulties were identified in the access to HCS, i.e. restricted access to the Specialized Outpatient Medical Care (SOMC), as well as limited access to innovative treatment and treatment abroad. ${ }^{13}$ We also found limitations in health prevention, limited access to rehabilitation services for people with disabilities, children with oncological or rare diseases, and prolonged deadlines for issuing a decision. During the study period, Bulgarian healthcare users reported serious difficulties in the implementation of European health cards, various limitations in medical team selection and violated rights of the health professionals and residency doctors. Additionally, the lack of effective procedures and administrative control of $\mathrm{HC}$ services was a problem in health insurance regulations of Bulgarian citizens living abroad. Similar findings were published in EUROOBSERVER's systematic reports ${ }^{23}$ as well as in the European Health Consumer Index surveys. ${ }^{24}$

The increased quantity of complaints could be considered evidence of the high confidence in the institution of ORB. Not surprisingly, the Bulgarian healthcare users seek assistance and support by ORB in terms of the inefficiency for alternative control mechanisms of HCS and patients support. It is apparent that the role of the ORB has the health users approval. This was supported by the results obtained from a recent social survey conducted by the Trend Research Center during last year. Two Bulgarian institutions have an approval rate more than $50 \%$ : the ORB, and the President of the Bulgarian Republic. Both achieved an approval rate of $63 \%$ vs. $53 \%$ from Bulgarian citizens. ${ }^{25}$ In a study by Bergman, healthcare users reported the following main functions of the ORB: to support the resolution of health problems, to listen and to clarify issues regarding HCS procedures. They also expressed that the ORB has the role of ensuring justice to foster an effective health policy, and also play a mediating role between the board of the BHCS, hospital managers and health users. ${ }^{26}$ The Bulgarian healthcare users have the right to receive quality health services. In this way, the public must act to ensure the full quality of the BHCS, which is not yet feasible. ${ }^{2}$ Furthermore, the ORB was shown to have an executive role that transcends its regular functions.

Many countries have experienced dissatisfaction with the parliamentary ombudsman because, for a variety of reasons, this official does not meet the patients' needs. Over the last three decades, in some EU countries among which some Balkan countries, as well as in Israel, New Zealand and Brazil, the public established a social control institution named health service ombudsman. ${ }^{27,28}$ Norway was the first country to introduce the institution of health service ombudsman as a complementary complaint mechanism. It supports more than 10,000 patients annually. ${ }^{29}$ The health service ombudsman plays a principal role in controlling the functioning of the public and private health institutions, parts of the HCS, as well as the national or private health insurance funds and companies. ${ }^{26}$ The objective of this official is to address the patients' needs and to resolve problems between patients and health providers. ${ }^{30}$ In some countries, such New Zealand, it goes even further and aims to improve the quality of the HCS. ${ }^{31}$ In Finland, the patient ombudsman represents the most restricted system and belongs to separate units of the HCS. It consists of a network of some 2,000 individuals, acting as advisers to patients within local healthcare providers. ${ }^{32}$ In UK, the health ombudsman is part of the parliamentary ombudsman system. It is usual for the health ombudsman to be organized as part of the governmental, regional, or local health administration and is funded by one of these administrative entities. ${ }^{33}$ In Israel, the health service ombudsman operates as an additional managerial or staff position within the HCS.34 In Norway, its functions are under the Directorate of Health, a decision making organ, responsible for implementing health policy regarding the Ministry of Health. This means that government is responsible for the health ombudsman and must inform Parliament about its structure and organization. 35

The idea of introducing a specialized constitutional body such a health service ombudsman in Bulgaria is not new. It was the subject of expert debate as early as 2006, one year after the introduction of the institution of Parliamentary Ombudsman in our country. ${ }^{14}$ The lack of sufficient data, experience and surveillance upon the work of the Parliamentary Ombudsman delayed this debate. Based on more than ten years of research since the introduction of the institution of Parliamentary Ombudsman in the Republic of Bulgaria, serious observations of its work has been done.

\section{CONCLUSION}

After a comprehensive analysis of the data included in the annual reports of the ORB, we identified the persistence of serious problems in the regulation, quality and functioning of the BHCS. Bulgarian health users denoted limitations of their rights, as well as restricted access to HCS. The greater number of complaints against HCS referred to the ORB that we observed during the last four years strongly suggests that the institution of the Ombudsman in Bulgaria enjoys high confidence among Bulgarian healthcare users. 


\section{IMPLICATIONS FOR THE HEALTH POLICY MAKERS IN BULGARIA}

Due to the above mentioned data i.e. higher confidence and rating of ORB, we propose to the health policy makers of our country to restart the debate on the establishment of a health service ombudsman in Bulgaria.

\section{Conflict of Interest}

The authors declare no conflict of interest.

\section{REFERENCES}

1. Dimova A, Rohova M, Moutafova E, et al. Bulgaria: Health system review. Health Syst Transit 2012; 14:1-186.

2. Dimova A, Rohova M, Koeva S, et al. Bulgaria: Health System Review. Health Syst Transit 2018; 20:1-230.

3. Council of Ministers/CoM (2017c). Portal for Public Consultations. Strategic documents. Healthcare. Available from: http://www.strategy.bg/StrategicDocuments/List.aspx?lang=bgBG\&categoryId=14\&t ypeConsultation=1\&typeCategory=0\&docType $=1$ ).

4. Ministry of Health/MoH (2018c). Annual Reports for the received by the $\mathrm{MoH}$ requests for access of public information for 2014, 2015, 2016, 2017, 2018. Available from: https://www.mh.government.bg/ bg/administrativni-uslugi/dostap-do-obshtestvena-informatsiya/ [Accessed 29 July 2019].

5. Executive Agency Medical Audit/EAMA (2016). Report on activity of the EAMA 2016. Ministry of Health, Sofia. Available from: http:// www.eama.bg/images/Dokladi/Doklad\%202016\%D0\%B3.pdf/ [Accessed 29 July 2019].

6. National Health Insurance Fund/NHIF (2019). Annual Reports for the received by the NHIF requests for access of public information for 2016, 2017, 2018, 2019. Available from: https://www.nhif.bg/ [Accessed 5 August 2019].

7. Bulgarian Drug Agency/BDA (2019 c). Register of pharmacies. Available from: http://www.bda.bg/bg/ [Accessed 5 August 2019].

8. National Insurance Institute (2017). Statistical Book Demography, Economy and Social Insurance 2016. Available from: http://www. nssi.bg/images/bg/about/statisticsandanalysis/statistics/pokazateli/ pokazateli_Demography_2016.pdf/ [Accessed 16 August 2019].

9. Cave E. Protecting patients from their bad decisions: rebalancing rights, relationships, and risk. Med Law Rev 2017; 25(4):527-53.

10. Mackenney S, Falberg L Conclusion. In: Mackenney S, Fallberg L, editors. Protecting patients' rights? Abingdon: Radcliffe Medical Press; 2004. Pp 137-48.

11. Pashkov V, Olefir A. Protection of children's rights in the health care: problems and legal issues. Wiad Lek 2017; 70:1122-32.

12. Regulation of the organization and activity of the ombudsman. Available from: https://www.ombudsman.bg/regulations/ombudsmanlaw.

13. Annual Report for the activities of the ombudsman $2005-2018$ and Annexes. Available from: https://www.ombudsman.bg/reports

14. The healthcare ombudsman - best practices and prospects for Bul- garia. Center for the Study of Democracy. Sofia 2006. Available from: http://old.csd.bg/fileSrc.php?id=1744/ [Accessed 12 August 2019]

15. Annual Report for the activities of the ombudsman 2006. Available from: https://www.ombudsman.bg/documents/gd2006.pdf. [Accessed 16 August 2019].

16. Annual Report for the activities of the ombudsman 2019. Available from: https://www.ombudsman.bg/pictures/REPORT-BG\%20 mart_2019(1).pdf/ [Accessed 16 August 2019].

17. Annual Report for the activities of the ombudsman 2015. Available from: https://www.ombudsman.bg/pictures/REPORT\%20OMB\%20 2015g_.pdf/ [Accessed 16 August 2019].

18. Annual Report for the activities of the ombudsman 2016. Available from: https://www.ombudsman.bg/pictures/REPORT_OMBUDSMAN_2016 (1).pdf/ [Accessed 22 August 2019].

19. Atanasova E, Pavlova M, Groot W. Out-of-pocket patient payments for public health care services in Bulgaria. Front Public Health 2015; 3:175.

20. Annual Report for the activities of the ombudsman 2018. Available from: www.ombudsman.bg/pictures/REPORT-BG\%20mart_2018. pdf/ [Accessed 22 August 2019].

21. Atanasova E, Pavlova M, Moutafova E, et al. Patient charges for health services: the opinions of healthcare stakeholders in Bulgaria. Int $\mathrm{J}$ Health Plann Manage 2015; 30:232-45.

22. Romaniuk P, Kaczmarek K, Syrkiewicz-Świtała M, et al. Health systems and their assessment: a methodological proposal of the synthetic outcome measure. Front Public Health 2018; 6:126.

23. Georgieva L, Salchev P, Dimitrova S, et al. Bulgaria: Health system review. Health Systems in Transition 2007; 9:1-156.

24. Björnberg A, Phang AY. Euro Health Consumer Index 2018 Report. Health Consumer Powerhouse Ltd., 2019. ISBN 978-91-980687-5.

25. Bulgarians' attitudes towards major parties and institutions (February 2019). Available from: https://rctrend.bg/ [Accessed 17 February 2019].

26. Berman LE. The role of the health care ombudsman. Manag Care Interface 2004; 17:37-40.

27. Fallberg L, Mackenney S. Patient ombudsmen in seven European countries: an effective way to implement patients' rights? Eur J Health Law 2003; 10:343-57.

28. Silva Rde C, Pedroso MC, Zucchi P. Ombudsmen in health care: case study of a municipal health ombudsman. Rev Saude Publica 2014; 48:134-41.

29. Molven O. The health and social services ombudsman (The patient ombudsman). In: Molven O, Ferkis J (Eds). Healthcare, welfare and law. Gyldendal Akademisk, Oslo, 2011, pp 165-75.

30. Fallberg L. Patient ombudsmen - a different approach to improve quality in health services. Eur J Health Law 2003; 10:339-42.

31. Paterson R. The patients' complaint system in New Zealand. Health Aff 2002; 21(3):70-9.

32. Finish Student health service. [Available from: https://asiointi.yths.fi/ en/patient_ombudsman/ [Accessed 14 September 2019].

33. Wise J. More complaints should be resolved locally, says health ombudsman. BMJ 2015; 351:h5636.

34. Doron I. Courts, ombudsman, and health care policy: an exploratory study of Israel's National health care insurance act. Eur J Health Law 2004; 11:391-405.

35. Molven O. Building a patient ombudsman scheme: the Norwegian experience. Med Law 2012; 31:57-70. 


\title{
Нуждается ли система здравоохранения Болгарии в омбудсмене по охране здоровья граждан?
}

\author{
Нигияр Джхафер ${ }^{1}$, Цекомир Воденичаров ${ }^{1}$, Янис Папатанасиу ${ }^{2}$ \\ ${ }^{1}$ Кафедра „Политика и менеджмент здравоохранения“, Факультет общественного здравоохранения, Медицинский университет - София, \\ Собия, Болгария \\ ${ }^{2}$ Кафедра рентгенологии, дентальной аллергологии и физиотерапии, Факультет дентальной медицинь, Медицинский университет - \\ Пловдив/ Кафедра кинезитерапии, Факультет общественного здравоохранения, Медицинский университет - София, София, Болгария
}

Автор для корреспонденции: Янис Папатанасиу, Кафедра рентгенологии, дентальной аллергологии и физиотерапии, Факультет дентальной медицины, Медицинский университет - Пловдив, бул. „Христо Ботев““№ 3, 4002 Пловдив, Болгария; E-mail: giannipap@yahoo.co.uk; Тел.: $+359889101178$

Дата получения: 27 октября 2019 Дата приемки: 20 ноября 2019 Дата публикации: 30 июня 2020

Образец цитирования: Dzhafer N, Vodenicharov T, Papathanasiou J. Does the Bulgarian health care system need a health ombudsman? Folia Med (Plovdiv) 2020;62(2):391-7. doi: 10.3897/folmed.62.e47655.

\section{Резюме \\ Введение: Должность омбудсмена Республики Болгария (ОРБ) является независимым конституционным органом, избран- ным парламентом Болгарии в 2005 году. Его задача - защищать права всех граждан, включая права пациентов, детей, ин- валидов, меньшинств, иностранцев и других лиц. Болгарские пользователи здравоохранения жалуются, когда считают, что система медицинского обеспечения (CMO) не отвечает их потребностям или что к ним применили неправильное лечение.}

Цель: Цель настоящего исследования состояла в том, чтобы проанализировать структуру и динамику всех жалоб от болгарских пользователей здравоохранения, направленных в адрес ОРБ за 13-летний период (2005-2018).

Материалы и методы: В настоящем исследовании использовалось ретроспективное документальное исследование. Данные включали жалобы, включенные в официальные годовые отчеты ОРБ, которые доступны в Интернете. В качестве источников также использовались библиографические и документальные поиски. Жалобы были проанализированы в соответствии с их годовым распределением и классифицированы в соответствии с проблемными областями в СМО.

Результаты: В период с 2005 по 2018 год в адрес ОРБ было подано в общей сложности 3288 жалоб на СМО. В 2015 году было получено 368 жалоб в адрес ОРБ от болгарских пользователей медицинских услуг и от различных организаций пациентов, касающихся проблем СМО. Жалобы на СМО увеличились на 82\% в 2016 году ( $\mathrm{n}=421)$. В 2017 году общее количество жалоб в адрес ОРБ достигло 494, а в 2018 году их было 607, что на 23\% больше, чем в 2017 году.

Вывод: Большое количество жалоб, направленных в адрес ОРБ на СМО за последние четыре года, однозначно свидетельствует о том, что институт омбудсмена Болгарии пользуется большим доверием среди болгарских пользователей медицинских услуг.

\section{Ключевые слова}

омбудсмен, болгарские пользователи медицинских услуг, жалобы, ограничения, права пациентов, доступ 